\title{
Demystifying the Hegemony of the English Language: Scrutiny of 'Gak Bisa Bahasa Inggris!' Advertisement within a Semiotics Lens
}

\author{
Ahmad Sugianto ${ }^{1 *}$, Ilham Agung Prasetyo ${ }^{2}$, Dewi Aria ${ }^{3}, \&$ Indiwan Seto Wahjuwibowo ${ }^{4}$ \\ ${ }_{1,2}$ Universitas Pendidikan Indonesia, Bandung, Indonesia \\ ${ }^{3}$ SMK Negeri 1 Tebing Tinggi, Tebing Tinggi, Indonesia \\ ${ }^{4}$ Universitas Multimedia Nusantara, Tangerang, Indonesia \\ *ahmadsugianto@upi.edu
}

\author{
ARTICLE HISTORY \\ Received : 19 August 2021 \\ Revised : 12 October 2021 \\ Accepted : 30 November 2021
}

\section{KEYWORDS}

\section{Advertisement}

Hegemony

English as a Lingua Franca

English as an International Language

Semiotic Film Analysis

World Englishes

\begin{abstract}
Due to its overarching status and power, the English language has dominated and influenced nearly in various means of communication, and one of which is instantiated in advertisements. However, studies concerning the hegemony of the English language represented in an advertisement were found to be under-explored. Thereby, the present study aimed to scrutinise the domination and power of the English language, particularly in Indonesia, represented in one of the advertisements, which is a remake video of a viral video from 2017 to date, entitled 'Gak Bisa Bahasa Inggris!' from a Youtube Channel named Pahamy. Semiotic analysis was employed to analyse the advertisement. The findings revealed only five out of eight types of syntagma found comprising descriptive syntagma, bracket syntagma, episodic syntagma, autonomous shot, and scene. The present study concluded that it seemed not possible to have the eight syntagmatic types in a very short advertisement video, and some signs found in the advertisement could be used to shed light on the hegemony of the English language in Indonesia, which might result in either positive or negative effect; hence, any thoughtful consideration and action through multilingual education was advocated to solve or at least mitigate this issue.
\end{abstract}

\section{Introduction}

The strike of globalisation has led to some shifts in every aspect of human life, and such an onslaught has provided various eminent phenomena. In this regard, one of the most profound phenomena has to do with the domination of one language over the others. The instance of this phenomenon is shown, for example, by the status of the English language, which is considered as the international language. In this case, Seidlhofer (2005) points out and lists a number of similar terms used by the theorists and scholars, for instance, English as a global language, English as a lingua franca, world Englishes, English as a world language, and English as a medium of intercultural communication. Again, due to such position and status of the English language, several influences and consequences emerge; as Modiano (2001, p. 341) asserts, "English is now prerequisite for participation in a vast number of activities... access to findings in science and technology, ... the entertainment field, as well as the arts, ... industrial, financial, and diplomatic arenas". Such conditions may be perceived that the English language 'has its ear to the ground' in which it seems it has gained numerous acknowledgements. Albeit the English language has obtained such domination, status, and acknowledgement, it has been recently challenged from the other languages that started to follow it as a global language, as reported from a survey by British Council, for instance, the Chinese language has gained its popularity and even is considered to be 'the most useful language in the future' (China Daily, 2017). Nevertheless, the opportunity of Chinese to take over the status, domination, and acknowledgement of the English language as an international language was doubted by Yano (2009) for China has numerous issues that may hinder it from gaining such privileges, such as limited energy and food resources indicated by its decreasing selfsufficient ratio for energy and food supply as well as the income inequality issue between the rural and urban areas. Another challenge derives from the Spanish language, which is also considered to be a global language, yet as Baker and Ishikawa (2021) assert, the global scale of its use is found to be limited; thus, the English language is still considered to be the more preferable, influential, and dominating global language in comparison with the other global languages, such as Chinese and Spanish. Such facts, in other words, indicate that the English language still holds its domination or hegemony around the world at present.

The hegemony of the English language is considered to be a crucial issue investigated by several researchers. It is due to the fact that this issue is perceived to result in some consequences, for instance, as Akujobi (2019, p. 13) argues, 
language death, that is, a condition in which languages come to extinction, "the loss of a people's identity and culture," and neocolonialism associated with the view in which a language is used as a means for controlling one's nation. Moreover, the status of English as a global language is increasing and strengthened by the way it penetrated into a country's educational system. In this regard, it is used as a medium of instruction in at least 55 countries (Dearden, 2014), and at the present time, it is supposed to surpass this figure because the use of English in daily lives has been growing extensively recently and has approached more than two billions users (Baker \& Ishikawa, 2021).

Moreover, particularly in Indonesia, albeit it is viewed as a foreign language, the English language is regarded to be one of the essential foreign languages. In this case, it is considered as one of the compulsory subjects at school started from secondary school level to higher education level (even in some regions in Indonesia, it has already been introduced at a primary school level (Kirkpartrick, 2011). Also, it becomes one of the subjects tested in school or university enrolments, or even it is one of the requirements as an individual is willing to apply for a job in a firm or company. In detail, Lauder (2008, p. 12-13) notes several functions or roles of the English language in Indonesia comprising "as a means of international communication, as an academic language, as a mean for achieving modernisation and development, as a mean for entrenching rapports with native speakers and their cultures, and as a tool to develop knowledge." Thereby, it is deemed as a prestigious language and may, for some extent, be considered as "an instrument of social stratification," (Akujobi, 2019, p. 2). Such conditions encapsulate that the English language has the power to the society, which, if it is not taken into account thoroughly, as Merriam (2009) contends, can marginalise and oppress those who are subordinates. Thereby, construing the phenomena having to do with the hegemony of the English language is necessarily carried out intensively so as to provide a thoughtful view concerning its impacts on every aspect of life.

In addition, advertisement as one of the means for transmitting or communicating messages, ideas, or products can be the site to shed light on the issue concerning the domination or power of the English language. It is, for instance, based on the evidence of a study conducted by Mizuta (2009), finding that the ideology of English is represented in eikawa (English conversation) schools through advertisements in which English is considered as the upper class and powerful and acknowledged language existed in her study. Moreover, such finding is crucial since advertisement has particular uses such as entrenching ideology and persuasive intention through the sign system or language it owns (Prasad, 2017). Thus, construing the meanings of signs represented in an advertisement can be worth studying. Moreover, the advertisement, taken from a
Youtube Channel named Pahamy, scrutinised in this study, constitutes a remake video from a viral video. The video was reported to be viral on various social media from 2017 to 2018 (Dewi, 2021). The viral video illustrates a male student meeting a stranger asking for direction using accent-like Thai to him. But without knowing what language the stranger was using, the male student surprisingly responded with "Nggak Bisa Bahasa Inggris!" (I cannot speak English). This phrase, said by the male student based on the writers' observation, was still found on many occasions, such as at school to date (ironically, it is frequently used as a joke by students during the English class). Thus, the writers view this issue concerning the hegemony of English with respect to the "Nggak Bisa Bahasa Inggris!" advertisement as worth scrutinising.

In addition, as for studying the meaning of the signs in the advertisement, Semiotics can be a valuable means of going through it. A number of scholars have developed frameworks for semiotic analysis. In this regard, there is one profound notion with respect to cinematography, advocated by Metz (1991), that can be worth trying to facilitate the analysis of the advertisement investigated in this study. Evidence has shown that this framework can be used to accommodate a study in finding the meaningmaking and discovery in terms of film for several issues, such as gender (Ali, 2018) and repression (Florina, 2014).

However, to the best of the writers' knowledge, studies concerning the hegemony of English using the semiotic film analysis were found to be limited. Many of the previous studies uncovered signs which had to do with other areas, such as gender differences or domination (Dwita \& Wijayani, 2018; Riani, Hidayat, \& Alek, 2021), marketing (Tsotra, Janson, \& Cecez-Kecmanovic, 2004; Zakia \& Nadin, 1987), political ideology (Briandana, 2019), self-actualisation (Syakur, Rusdiawan, \& Sukri, 2018). Meanwhile, a study inspecting the same variables as our study, i.e., the status of the English language concerning the advertisement, was conducted by Hoffman (2016). Nevertheless, she employed a critical discourse analysis as a tool to analyse the artefact, whereas a semiotic film analysis was utilised in our study. The other instance was conducted by Mizuta (2009), who employed the hegemony theory advocated by Gramsci (1971) to see the ideology of English by going through 150 advertisements. Also, another previous related study was conducted by Manan, David, Dumanig, and Channa (2017), who utilised a linguistic landscape framework (Landry \& Bourhis, 1997) to analyse an advertisement. Based on the previous studies above, our study is considered to have differences to some extent from them. Thus, it is considered to be worth scrutinising to see the viability of the semiotic film analysis to investigate the variables concerned, namely those that have to do with the hegemony of the English language in the advertisement. Thereby, based on the rationales mentioned above, this study aimed at scrutinising the 
meanings of the signs associated with the hegemony of the English language in the advertisement video through utilising the semiotic film analysis embedded in syntagmatic types. Additionally, this study posed research questions to guide it: 1) What are the syntagmatic types employed by the advertisement? 2) What are the meanings of the signs with respect to the hegemony of the English language in the advertisement?

\section{Literature Review}

The following section will focus on the variables involved in this study. These encompass the construal of the advertisement conceptions with respect to the way it is used in social interactions and communications, followed by the understanding of the domination of the English language and film semiotics.

\subsection{Advertisement and Communication in Society}

At the present time, advertisement has been one of the essential means of communication in regard to economy, politic, culture, and even education. It is seemingly so ubiquitous that it can be found in various media, either printed or electronic (Saputri, Hidayat, Alek, \& Eviyuliwati, 2021). Besides, it is considered to be an eminent tool through which particular messages can be communicated in comparison to any other forms of communication (Grimaldi, Hadeler, Richards, Berger, Zimmerman, Bromley, Dapper, Toth, Santry, \& Allen, 2003; Tenia \& Saripudin, 2019). In addition, the advertisement realised through a variety of modes or means encompassing print, broadcast, outdoor, direct mail, collateral material, and the internet has particular features which may be either positive or 'negative,' informative or persuasive, intended to help the viewers/readers critically observe the strength and weakness of a product or to merely persuade them so that they buy the product (Cayestu \& Pasaribu, 2020).

In addition to the features of advertisements, upon having power over particular individuals, such as youth or individuals with a lack of education, an advertisement can be an influential tool infusing a subtle or hidden social agenda affecting them (Feramayasari \& Wiedarti, 2020). Another feature is leading advertisements to be enticing to investigate due to their language use, which in this regard is characterised by 'mysterious of language' in its production
(Dahl, 2007). Furthermore, the use of the language in the advertisement will be significant if it conforms to the images emerging in the advertisement (Afsheen \& Eijaz, 2017). Thereby, the significance of the advertisement will not run per se, but the images accompanying it also have a particular role, namely in delivering the purposeful message (Sugianto, Denarti, \& Prasetyo, 2021). Moreover, at present, the information concerning the purposeful message can be easily accessed due to the fact that lots of today's advertisements have been aired on ubiquitous social media such as Youtube (Al Mar'atus \& Syahrizal, 2021; Tussa'diah, Anggaini, \& Hasibuan, 2021).

In conclusion, based on the elaborations above, advertisements are considered as the essential means of social communication and interaction. These can be in printed or electronic forms. Also, the content provided by an advertisement can result in positive or negative impacts, so the viewers are required to entrench their critical thinking as they view it.

\subsection{The Hegemony of the English Language}

The impacts of the domination or the hegemony of the English language constitute the result of its spread around the world. In this regard, Kachru $(1986,1996)$ points out the geographic and historical spread of the English language represented in three types of circles encompassing: 1) the inner circle associated with the countries which constitute 'the traditional bases of English' and the English language is used as the 'the primary language'; 2) the outer circle or 'extended circle' associated with the countries in which the English language is deemed as as a second language and the "part of a country's chief institutions'; 3 ) the expanding circle or 'the extending circle' having to do with countries in which the English language is considered to be an international language and historically the countries included in this circle had not undergone colonialisations of the coutries from the inner cirlce (Cystal, 2003), albeit for a certain case, for instance, actually Indonesia had ever been colonialised by English in the past time, around the eighteenth century, as it was formerly known as the Netherlands East Indies (Israel, 1995, p. 1127; Kehoe, 2008). In addition to the representation of the three circles, the countries that belong to each circle are depicted in detail in Figure 1. 


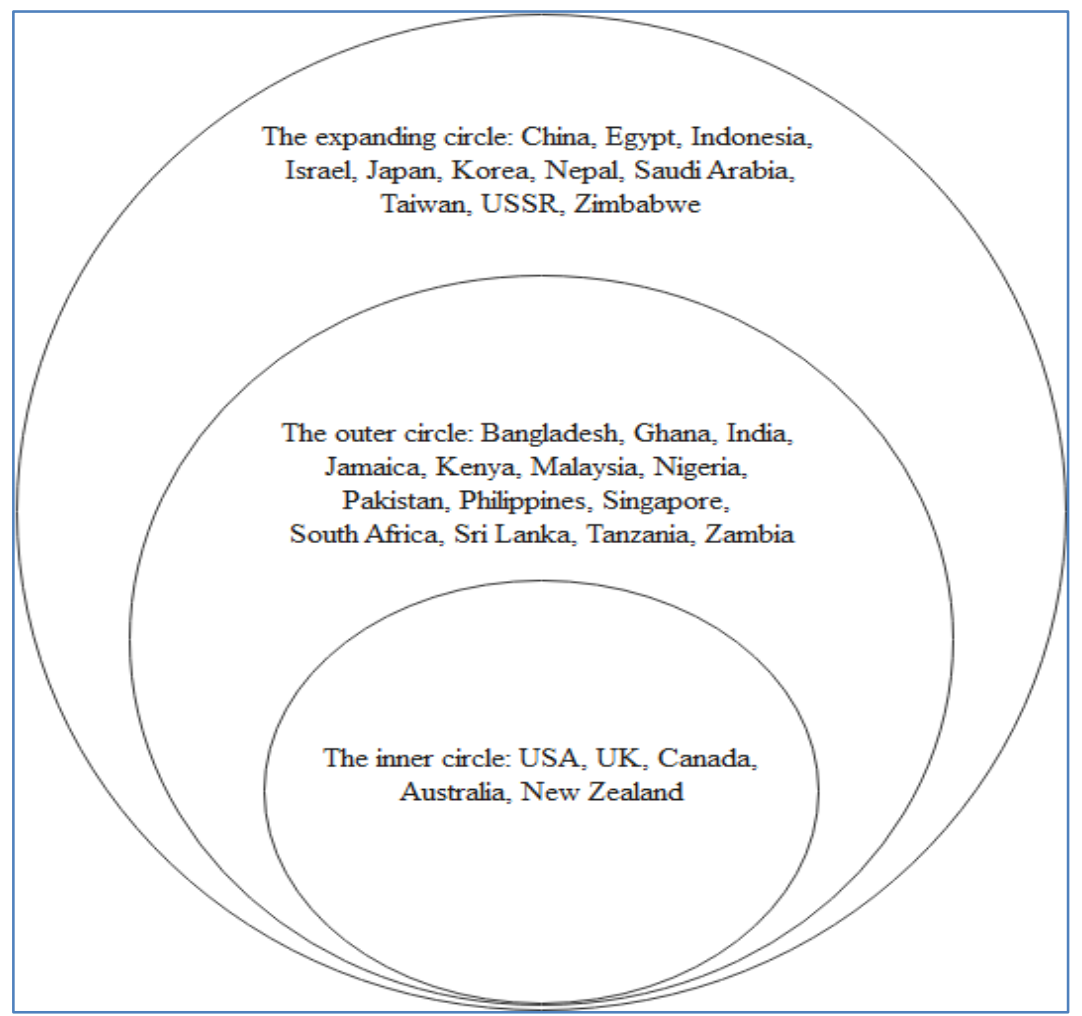

Figure 1. The Three Concentric Circles (Kachru, 1988, 1996)

Moreover, the domination and power of the English language can be represented through various means. In this regard, such representation depicting the hegemony of the English language, as some studies show and reveal, can be in the form of a written such as a book (Mianda, 2014) and a video or movie (Jonesa, Jufrizal, \& Wahyuni, 2018). Additionally, the hegemony of the English language may result in certain fashions. On the one hand, it may result in negative effects, such as making the other languages come to extinction, "the loss of a people's identity and culture," and neocolonialism (Akujobi, 2019, p. 13). On the other hand, instead of negative consequences, the existence of the domination of the English language may result in a positive consequence, and if there is a lack of domination of the English language may bring some negative impacts to particular countries. In this regard, Tom-Lawyer and Thomas (2019, p. 92) reveal such conditions in which the non-hegemony of English in Western Africa underwent based on some studies, for instance, led to the following issues comprising of low literacy rate, high poverty rate, industrial backwardness, social and employment mobility became limited, prevalent school drop-out rate, limited access to information, and limited career opportunities.

Based on the elaborations above, the domination of the English language can be concluded to have two main results or impacts, i.e., either provides positive impacts or negative ones. Thus, this issue is required to be taken into account thoughtfully, for these may influence individuals or countries in some aspects, for instance, in the aspects of the economy, political, education, and so forth.

\subsection{Film Semiotics: What is it?}

Semiotics constitutes one of the growing interests and fields in the area of language and communication. Moreover, semiotics, according to Gall, Gall, and Borg (2003, p. 507), is defined as "the study of sign systems, in particular, the study of how objects (e.g., letters of the alphabet) come to convey meaning and how systems relate to human behaviour." In addition, the importance of the study of signs becomes clear with the realisation that message doesn't exist until it has become coded in the form of signs. This coding process affects the nature of the message that is delivered." Besides, semiotics derives originally from the two prominent figures, namely Charles Sanders Peirce, the American pragmatic philosopher, and Ferdinand de Saussure, the Swiss linguist (Stam, Burgoyne, \& Flitterman-Lewis, 2005).

Moreover, due to its use to understand the meaning of messages, semiotics has been implemented in several communication media, one of them has to do with the film. The meaning-making is manifested in the film is conducted through some cinematographic scenes known as the Large Syntagmatic Category of the Image Track. Regarding the Large Syntagmatic Category of the Image Track advocated by Metz (1991), there are eight syntagmatic types which are explicated in Table 1 below. 
Table 1. Syntagmatic Types

\begin{tabular}{ll}
\hline Syntagmatic Types & Description \\
\hline Autonomous shot & A single shot. There are some subdivisions of this syntagmatic type, namely \\
single-shot sequence and inserts (comprising non-diegetic insert referring to \\
the image with the comparative function used to show the external object of \\
the film, displaced diegetic insert referring to the real diegetic image \\
displaced from its normal film position, i.e., temporally or spatially out of \\
context, subjective insert referring to images describing memory, dream, \\
fear, etc., explanatory insert associated with the single shots used for events \\
clarifications to the viewers.
\end{tabular}

Parallel syntagma

Bracket syntagma

Descriptive syntagma

Alternate syntagma

Scene

Episodic sequence

Ordinary sequence
A combination of two or more distinct and unrelated plots (i.e., there is no direct relationship in terms of the setting of time or place).

Short scenes are used to show particular examples of a certain order of reality without temporal sequence and frequently appear around a concept.

Successive objects describe "spatial coexistence"; in other words, it has to do with providing a particular description of the setting of a certain object.

Provides the explanations of two or more events or plots simultaneously. Also, it occurs in the same story having a direct relationship in terms of the settings.

Particular events occurred in a certain set of times or places. Also, the signifier indicates the events fragmented into various shots.

Used to shorten time chronologically, orderly, and symbolically.

Used to show the only necessary shot which is not used chronologically.

(Metz, 1991, p. 119-131; Stam, Burgoyne, \& Flitterman-Lewis, 2005, p. 41-42; Wahjuwibowo, 2018, p. 38-41)

Some previous studies have shown that the syntagmatic types above are facilitative to assist the analysis of the meaning-making and discovery concerning issues encompassing gender (Ali, 2018) and repression (Florina, 2014). Based on these previous studies, it is perceived to be worth trying to apply these syntagmatic types to figure out the meaning of the signs that appear in the artefact concerned in the present study.

\section{Method}

Qualitative research, more specifically a semiotic analysis, was employed in the present study. In this case, this type of analysis, in some resources, seems to have other related terms, for instance, hermeneutic analysis, which was deemed as the type of analysis having to do with evaluating and discovering meaning from a particular text involving speech, movies, or songs, and cultural artefacts (Shank, Brown, \& Pringle, 2014) and content analysis (Schreier, 2012). However, semiotic analysis is preferred to be used as this study involved and was focused on syntagmatic analysis, which is a part of a semiotic analysis (pp. 51-52).

Besides, the analysis unit investigated in this study was an advertisement taken from Youtube. Its title was " $G a k$ Bisa Bahasa Inggris!" created by Pahamy and uploaded on
January 29, 2021 (Pahamy, 2021). This was investigated due to the virality of the plot in various social media and on account of the perceived assumption that the content had the related issue concerning the portrayal of the domination and power of the English language.

As the artefact or the analysis unit were collated and downloaded from Youtube, following and adapting Jewitt, Bezemer, and O'Halloran's (2016, pp. 147-148) notions concerning the multimodal transcription, it was transcribed (which in this regard it is introduced by them as a process of 'transduction' comprising different modes, such as writing, image, and layout). When these had been transcribed, these were identified and analysed by utilising the semiotic film analysis, i.e. Metz's (1991) Large Syntagmatic Category of the Image Track. In this regard, the verbal and nonverbal signs emerging in the advertisement video were analysed based on the eight syntagmatic types comprising autonomous shot, parallel syntagma, bracket syntagma, descriptive syntagma, alternate syntagma, scene, episodic sequence, and ordinary sequence. The analysis conducted was used to construe and infer the findings concerning the representation of the hegemony of the English language. 
In addition, to make sure the present study meets the trustworthiness, some verification techniques were utilised. First, "long terms and repeated observation" associated with scrutinising the issues for a particular length of period to make sure the data were valid based on the setting involved were employed (Creswell, 2014). Second, peer debriefing was conducted through consulting the work to the professional concerning the area scrutinised; also, generating the thick description of the data obtained was employed to keep transferability of this study, which may facilitate feasible comparisons with the other contexts; besides, creating "referential adequacy" by searching and using related documents, theories, and previous studies were employed to corroborate the findings and the interpretation of the data analysed (Guba, 1981).

\section{Results}

The findings of the present study were based on the syntagmatic types advocated by Metz (1991). In this case, these were displayed based on the plots that occurred in the advertisement consecutively.

\subsection{Descriptive syntagma 00:00 -00:25 = 0}
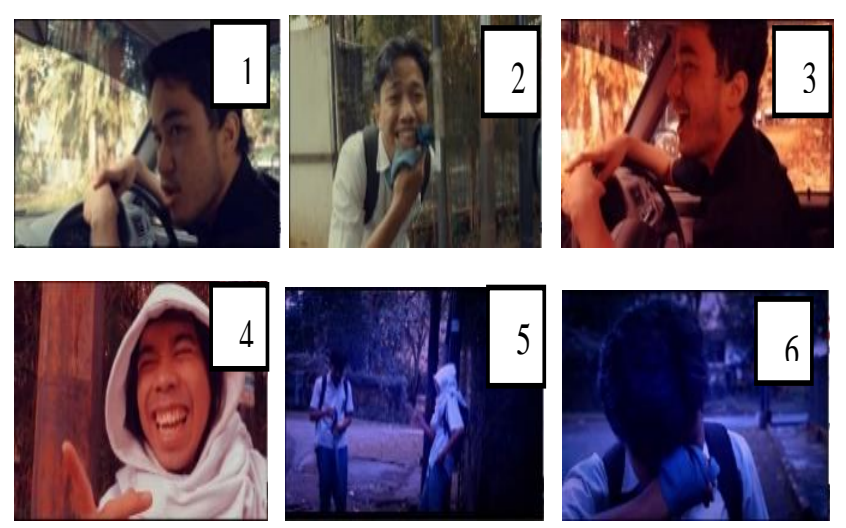

Figure 2. The Senior High School Student Met the Driver for the First Time (Pahamy, 2021)

The descriptive syntagma was found in the initial scenes. In this regard, these initial scenes provide some description of the initial introductory plots of the film. To begin with, these scenes tell about a driver who was greeting a male senior high school student being on the way to school. The driver was likely to speak in Thai. Regardless of having no understanding about what the man was talking about and what kind of a language the man used, the boy, the senior high school student, just replied it "I don't understand. ... I can't speak English." Knowing the boy could not speak English, the driver and the other boy, who is a senior high school student too, laughed at him. Being laughed at, the main actor, the male senior high school student, unfastened his school tie and tried to wipe his tears.
In this segment, the depiction is also given by varying the hue of the scenes. In this regard, image 1, when the driver was greeting the student, and image 2, as the senior high school student was answering, was in a normal hue. However, after the boy told the man that he could not speak English, there were some colour differences concerning the scenes. Image 3 and 4 had the orange colour indicating "cheer and excitement" (Morton, 2021b); concerning the plot of the film, the shift of colour can be interpreted that the two actors in the film in images 3 and 4 were feeling pleased with the condition as a result of hearing the other actor, the boy could not speak English. Moreover, the image 5 and 6 turned into blue meaning "depression" (Morton, 2021a); such colour, if associated with the plot, then can be interpreted as being unable to speak English or having a lack of English proficiency made someone depressed; in other words, English has a power to control one's emotion.

\subsection{Scene $(00: 26-00: 38=0)$}

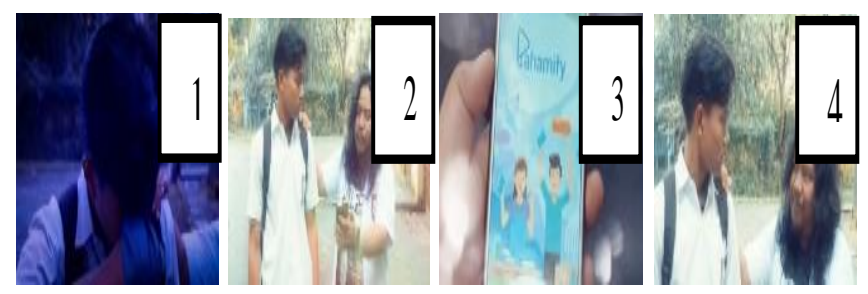

Figure 3. The Senior High School Student Met Another Student Showing Him a Learning Application (Pahamy, 2021)

This type of syntagma comprises several shots, which are chronological, and consecutive, and linear. In these scenes, the senior high school student, who seemed to be depressed after being bullied by the driver and the other student, met another actor that was likely a senior high school student too. In this scene, the other student with long hair was depicted as a "saviour" who was trying to soothe the main actor by showing him an online learning application named Pahamy. Although there was no dialogue as the two actors met, referring to the gestures carried out, the meaning of the scene is still intelligible. In this regard, the actor with the long hair seems to give advice or suggest to the main actor to keep calm as indicated by his hand, which is touched the main's shoulder; such touch can be interpreted as support (Jones \& Yarbrough, 1985). In the last scene, both of them nodded as if showing an indication that the main actor was in agreement (Andonova \& Taylor, 2012) that they would try to use it. 


\subsection{Bracket Syntagma 00:39-00:43 = 0}
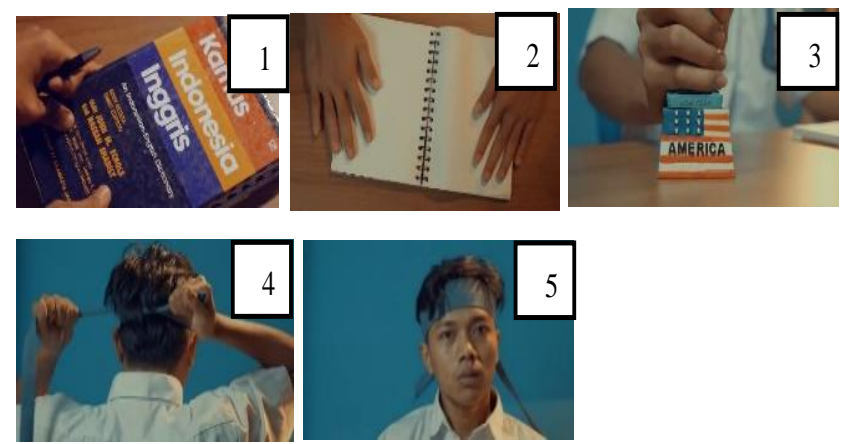

Figure 4. The Senior High School Student Was Preparing to Study English (Pahamy, 2021)

As its name, this type of syntagma encompasses a mélange of short shots. This scene depicts the several shots having to do with the preparation before the main actor studied English. In this case, as portrayed in Figure 4, an amount of equipment was prepared by him, for instance, a bilingual dictionary (Bahasa Indonesia-English), a notebook, a miniature of Liberty statue with a flag and writing of "America," a grey senior high school tie used as a headband. All this equipment can be interpreted as he was ready to learn English. Moreover, more specifically based on Figure 3, image 1 showing a bilingual dictionary (Bahasa Indonesia-English) can be interpreted that the boy was focusing on learning English as the target language from Bahasa Indonesia as the source language, and it also indicates that the boy knows Bahasa Indonesia better than English. Also, by referring to the empty notebook indicated by image 2 , it can be interpreted that it is just the beginning of his learning. Next, the miniature of Liberty statue shown in image 3 can be interpreted as he is learning English, and/or specifically the American English, or in a figurative fashion, it can be associated with the notion of freedom (Maguth, Dustman, \& Kerr, 2013); in this regard, if it is connected to the plot, it can be interpreted as the boy aimed to achieve for his freedom by acquiring the English (speaking) ability. At last, images 4 and 5 showing the man wearing a tie and fastening it as a headband can be interpreted as a symbol of courage (Hasan, 2018); hence, he would never give up on learning English.

\subsection{Episodic Sequence (00:43-56:00 = 0)}
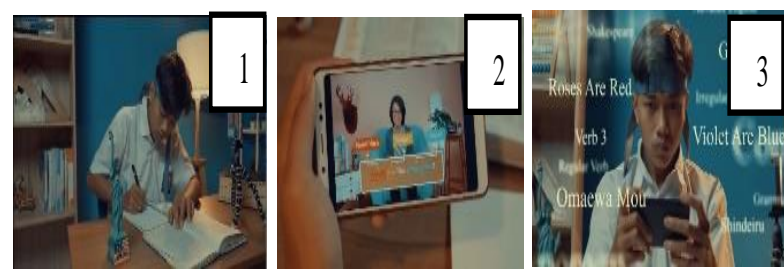

Figure 5. The Senior High School Student Was Studying English (Pahamy, 2021)
As its name, this type of syntagma shows the plots consecutively and linearly and commonly comprises more than one-shots with the functions to shorten the time chronologically. In this case, this scene depicts the boy who was studying English by utilising the online learning application, Pahamy. Moreover, based on Figure 5, image 1 shows that he was noting down the materials that he obtained from watching an English female tutor online by using his smartphone shown by image 2 . Then, in image 3 , it seems that all the materials conveyed by the tutor were intelligible for him. Based on these scenes, it can be interpreted that the boy was studying English seriously and in a motivating fashion by referring to the way he noted down the materials; in other words, it can be interpreted that he was engaged on account of the conducive environment for learning he created as shown by the attributes aforementioned (Schunk \& Mullen, 2012). Also, it provides information that the boy had understood the material given, as indicated by the gesture of a nod in image 3 (Andonova \& Taylor, 2012).

\subsection{Autonomous Shot (00:56-01:00 = 0)}
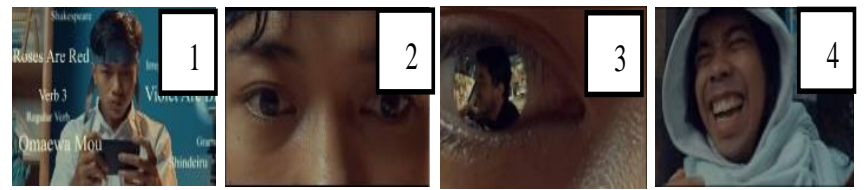

Figure 6. The Senior High School Student Remembered the Insults He Got on Account of His Lack of English Proficiency (Pahamy, 2021)

The autonomous shot, including subjective insert, occurs as the main actor, the male senior high school student, was studying English at home, and he was depicted to remember the events and insults he obtained through his eyes. This scene was enclosed by the background sound, that is, a sound of an eagle. The sound of an eagle and his eyes shown in image 3 can be interpreted that the boy was targeting and readily hunting (Wittkower, 1939) or "assaulted" or took revenge on the other actors who had already insulted him for not having adequate English language skill.

Moreover, the scene depicting the insults he got as he was on the way to school, which in this case, the other actors laughed at him because he could not speak English then can be interpreted that the ability to speak English is considered as an essential and prestigious competence. Lack of such ability is viewed as something weak and deficient. Such portrayals indicate that the use of language, which in this case particularly English, may lead individuals to see or label someone else's status (McKinney, 2007), which then results in particular consequences, such as obtaining less access to certain public services (Dubard \& Gizlice, 2008), affecting employment status (Afful, 2014). 


\subsection{Scene $(01: 00-01: 39=0)$}
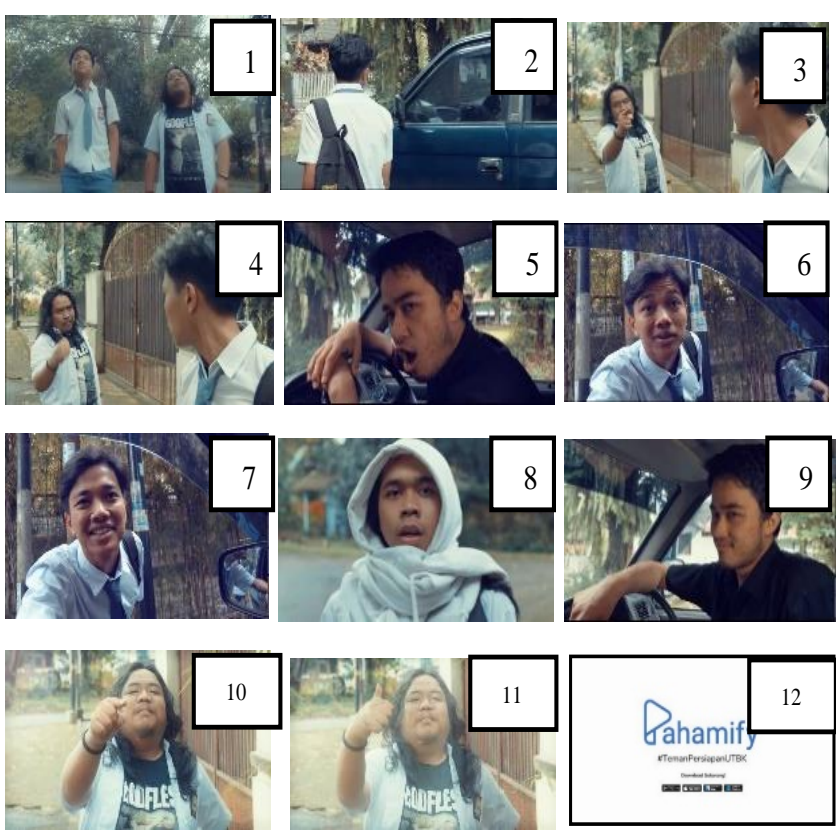

Figure 7. The Senior High School Student Met the Driver Again (Pahamy, 2021)

This scene depicts the plot in which the main actor with the other student who was on the way to school and suddenly a car horn honked and stopped near to them. Knowing that the car was the same as the previous day he met, the main actor turned his head and saw the student with long hair. Then, the student with long hair pointed to him and gave a distance fist pump to the boy. Then, the boy came close to the car, and the driver greeted him in the Thai language. The boy just directly replied to him with, "Sorry, I don't speak Thai." Knowing that boy had been able to speak English, the driver and another student who laughed at him the previous day seemed to get surprised. Then, the other student with the long hair pointed his finger to him and gave him a thumb up. At last, the student with the long hair disappeared, and the insignia of the online learning application appeared with a white background. Based on this scene, there are some gestures used by the actors that have some interpretations. For instance, the man with the long hair pointing to him with the index finger and giving a fist pump can be interpreted as wishing him "good luck" (Charles, 2018; Devereux, 1966; Mehrabian, 1969). Moreover, in terms of the thumb up used, it can be interpreted as the boy with the long hair was appreciating the main actor that he had done a good job (Sherzer, 1991).

\section{Discussion}

Based on the aforementioned findings, it can be seen that not all the types of syntagma appear in the advertisement. In this regard, only five out of eight types of syntagma come up in the advertisement, i.e., descriptive syntagma, bracket syntagma, episodic syntagma, autonomous shot, and scene. This finding follows the result of a study conducted by Ali (2018), who also found that not all the syntagma types appear, which in this regard, in his study, there was no bracket syntagma. In comparison with the finding of the previous study investigating a film with more than one and thirty hour-duration, it can be inferred that to cover all the syntagma types in one advertisement like the present study that has a very short duration, i.e., about one minute and thirty-nine seconds seem challenging and unlikely.

Furthermore, the findings of the present study also follow the findings of the previous studies (Manan et al., 2017; Mizuta, 2009) that reveal the ideology, as well as the domination of English, were embedded in advertisements. However, so as to clarify that the present study is considered to provide a new insight since it was conducted in the context of Indonesia and uses the semiotic lens, i.e., syntagmatic types, to analyse the artefact. In this regard, some indications concerning power and domination can be illuminated through several signs. To begin with, the advertisement is a remake video from a video depicting the similar story of a male teen student who was viral due to his reaction toward a stranger who was talking to him, and due to his unfamiliarity with what the stranger talked about, he just reacted by saying "Tidak Bisa Bahasa Inggris" (Can't speak English)." This video uploaded on Youtube was viral which then was adapted by Pahamy to make the remake video for its commercial use. The use of Youtube, which was considered as a cultural product, as Bestari, Mayekti, and Faiza (2020) contend, can be associated with the domination of the United States (US), which in this case, the US constitutes one of the countries in the inner circle in which English becomes the primary language (Kachru, 1986, 1988, 1994, 1996, 2001). Based on this finding, the power and domination of the English language can be indicated by the ability to speak English, and the use of Youtube viewed as a cultural product that becomes the common media to promote or share the information about a product (in this case the product was in the form of service); besides, these also provide the emphasis that the English language and culture have gained its power in Indonesia to some extent.

Moreover, some signs indicating the domination and power of the English language were found inside the advertisement video. In this case, similar to the previous finding, it was found that those signs had to do with the (American) English and its cultural product associated with concrete cultural objects (Sugianto \& Wirza, 2021; Yuen, 2011), as shown by the small miniature of the Liberty statue shown in the video during the main actor is trying to learn English at home (see the episodic sequence and bracket syntagma above). Moreover, another sign having to do with the (American) English relates to the bilingual dictionary (Bahasa Indonesia-English) used, which in this case was 
written by John M. Echols and Hassan Shadily, which tend to have an American English nuance (see the episodic sequence and bracket syntagma above). Nevertheless, it seems that the use of the bilingual dictionary was considered not appropriate since, as Budiwiyanto (2021) argues, it was considered to be a receptive dictionary with a function to decode messages from the target language and more suitable for English speakers, not Bahasa Indonesia speaker, besides it was not deemed to be friendly-user, particularly for a beginner learner, that in this case was associated with the actor in the advertisement video.

In addition to the signs symbolising the hegemony of the English language, the other syntagma types also reveal them. In this regard, the signs associated with the emotions appearing in descriptive syntagma (00:00 -00:25) in the initial plot and the scene syntagma (01:00-01:39) appearing in the last plot. In the descriptive syntagma (Figure 2), the main actor, the male student, felt "down" because he was not able to speak English, and due to such weakness, he got insults from the other actors, namely the driver and the other student passing by the street. In this scene, there are some changes in terms of the actors' emotions. The shifting emotions were shown by the changing of the colours in the scene, i.e., the main actor who felt depressed was shown by the blue colour scene (shots 5 and 6 of the descriptive syntagma), and the other actors who insulted him were shown in the orange colour (shots 3 and 4 of the descriptive syntagma). By using the different colours, the producer or maker of the video seemed to show the emotions of each actor. It is in line with Morton's (2021c) assertion that each colour has its own meaning. Moreover, most of the shots are taken in close-up shots. Such close-up shots, as Ali (2018) asserts, were employed to show particular emotions. Moreover, in the last scene syntagma, the main actor met again with the driver who had insulted him; but in this scene, because he was able to speak English, he got no insults from the driver; on the contrary, he obtained an acknowledgement from the driver indicated by the driver's gesture, i.e., nodding. Also, being able to speak English made the main actor respond to the driver with a big smile showing that he was quite confident to talk to the driver. This plot indicates the power of the English language in which the ability to speak English may bring dignity, as shown by the main actor's big smile and the acknowledgement of the driver to the main actor.

Furthermore, the depiction of the hegemony represented in the video results in some impressions. On the one hand, as can be seen in the previous section, the lack of ability in using the English, some insults were given to the main actor. On the other hand, the domination of the English language may lead to the communication between two people from different cultures or languages is feasible, as it can be depicted in the advertisement in which the driver seemed to speak in Thai whereas the main actor whose first language was Bahasa Indonesia could communicate each other by making use of English (Figure 7, the scene 01:0001:39), and the message seemed intelligible which was indicated by the driver gesture, i.e., nodding. This finding follows the notion revealed by Master (1998), who views 'universal access' associated with the use of the English language universally that may accommodate a particular communication, in this regard in particular that which has to do with intercultural communication (Baker, 2018). Moreover, particularly in the higher education context, as Formentelli (2017) reveals, the ability to use English becomes more crucial, and in some sorts, he reports that it has been the language of higher education; such condition was due to the phenomenon of the internationalisation of higher education' which goes along with the trend to use English as a common medium (Kirkpartrick, 2011); hence, there seemed an increasing trend of the students studying overseas in countries from the inner circle such as United States (26\%), United Kingdom (15\%), Australia (8\%), and Canada (3\%) (OECD, 2016, p. 331). In other words, the English proficiency that students have may be beneficial for them, along with the condition in which if they are studying overseas, that may accommodate them during their interaction showing as part of the global community.

Albeit it was considered to provide a positive effect in communication and particularly in the academic context, it should be noted thoroughly that such domination of the English language may diminish the existence of the national language or local language. Pennycook (2017) reports that this phenomenon occurred in Malaysia in which lack of the national language Bahasa Malaysia proficiency was found; most of the citizens were found to be more proficient in the English language in comparison with their national language, Bahasa Malaysia. Thereby, even though undoubtedly, English has some crucial roles and functions, for instance, comprise the language required in the workplace, the medium of instruction, particularly in higher education levels, the media, and the internet communication (Graddol, 2000; Kirkpartrick, 2011; Modiano, 2001), any thoughtful considerations for its use that may backfire on the existence of the national language or even the local language are required to be taken into account. To this end, carrying out the multilingual education as well as introducing the local languages or mother tongue at the primary school level which were also perceived by some researchers to provide benefits such as promoting 'multiple linguistic, cognitive and intercultural resources' needed for learning the other languages can be promising alternatives and agendas, particularly for Indonesia since it is considered to be 'the house of multicultural ethic groups' in which numerous 'individual vernacular languages' exist, approximately exceeding seven hundred languages (Benson, 2017; Cenoz, 2009; Kirkpartrick, 2011; Saputra \& Saputra, 2020). 


\section{Conclusion}

Based on the elaborations of the aforementioned findings, some conclusions can be drawn. To begin with, it is a rare phenomenon to find a very short advertisement that covers and makes use of all the syntagma types; in this regard, only five out of eight types of syntagma emerge, i.e., descriptive syntagma, bracket syntagma, episodic syntagma, autonomous shot, and scene. Next, the power and domination of the English language were shown by the use of Youtube viewed as a cultural product, deriving from the United States (US), as a means for advertising a product with the plot giving the emphasis that it is crucial to have apt English-speaking proficiency.

Furthermore, some signs embedded in the advertisement video found to have an association with the hegemony of the English language comprise the cultural products which mainly derive from and tend to have a relation with the US, for instance, the small miniature of the Liberty statue and bilingual dictionary used that were shown particularly through the episodic sequence and bracket syntagma. The hegemony of the English language was also found in the other types of syntagma, namely the bracket syntagma and scene syntagma, with some features such as the use of shifting colours in some particular shots and the use of close-up shots indicating the emotions of the actors, and the use of the actors' gestures.

In addition, the domination and power of the English language have both negative and positive effects and impressions; which in this regard, the former associated with the ability to speak English shown in the video, namely any acknowledgement will be given to those who have the apt English proficiency and vice versa if one lacks such proficiency may result in a consequence such as insults leading to depressed feeling; the latter associated with the intercultural communication; which in this case, the English language can be used as a medium to facilitate the interaction and communication conducted by people with different cultures and languages. Fifth, the negative effect of the hegemony of the English language over the existence of the national language or local language is required to be taken into account, and the multilingual education proposal can be an alternative to solve it. Finally, for future studies, interviewing the producer(s) or maker(s) of the video are advocated to gain more in-depth data, particularly that have to do with the meanings of the signs appearing the video; moreover, investigating the advertisement by making use of the other framework can be alternative for the future research.

\section{References}

Afful, E. A. (2014). Heterogeneity in the importance of English-speaking ability in determination of employment status by demographic subgroups in the United States. In Munich Personal RePEc Archive
(MPRA). The Munich University Library. https://mpra.ub.uni-muenchen.de/58767/

Afsheen, S., \& Eijaz, A. (2017). What makes an educational advertisement campaign successful: A case study of Zara Sochiye. Journal of Media Studies, 32(2), 61-88.

Akujobi, O. S. (2019). The English language hegemony and sociolinguistic effects on indigenous Nigerian languages. Journal of African Studies and Sustainable Development, 2(2), 1-14.

Al Mar'atus, A., \& Syahrizal, T. (2021). The analysis illocutionary acts of ustadz Hanan Attaki Youtube channel. PROJECT (Professional Journal of English Education), 4(1), 47-54. https://doi.org/10.22460/project.v4i1.p47-54

Ali, M. M. (2018). Analisis gender film Salah Bodi melalui semiotika Christian Metz. Gelar: Jurnal Seni Budaya, 16(1), 59-76. https://doi.org/10.33153/glr.v16i1.2340

Andonova, E., \& Taylor, H. (2012). Nodding in (dis-) agreement: a tale of two cultures. Cognitive Processing, 13(1), 79-82. https://doi.org/10.1007/s10339-012-0511-7

Baker, W. (2018). English as a lingua franca and intercultural communication. In J. Jenkins, W. Baker, \& M. Dewey (Eds.), The Routledge handbook of English as a lingua franca (pp. 25-50). Routledge.

Baker, W., \& Ishikawa, T. (2021). Transcultural communication through global Englishes. In Transcultural Communication Through Global Englishes. Routledge. https://doi.org/10.4324/9780367809973

Benson, C. (2017). Multilingual education for all: Applying an integrated multilingual curriculum model to lowincome contexts. Multilingualisms and Development, 101-114. British Council

Bestari, A. C. Y., Mayekti, M. H., \& Faiza, D. (2020). Short documentary film implementation at Al Ikhsan Beji Islamic boarding school as a media to improve English speaking in the midst of the American popular culture hegemony. Jurnal Sinestesia, 10(1), $22-31$.

Briandana, R. (2019). Representation of political ideology in advertising: Semiotics analysis in Indonesia television. International Journal of English Literature and Social Sciences, 4(3), 764-775. https://doi.org/10.22161/ijels.4.3.31

Budiwiyanto, A. (2021). Urgensi penyusunan kamus dwibahasa Indonesia-Inggris untuk penutur Bahasa Indonesia. Badan Pengembangan Dan Pembinaan Bahasa Kementrian Pendidikan Dan Kebudayaan. 
http://badanbahasa.kemdikbud.go.id/lamanbahasa/con tent/urgensi-penyusunan-kamus-dwibahasa-indonesiainggris-untuk-penutur-bahasa-indonesia

Cayestu, T. A. A. B., \& Pasaribu, T. A. (2020). Ellipsis on gadget advertisements in T3 magazine. JELTL: Journal of English Language Teaching and Linguistics, 5(1), 105-119. https://doi.org/10.21462/jeltl.v5i1.390

Cenoz, J. (2009). Towards multilingual education: Basque educational research from an international perspective. Multilingual Matters. https://doi.org/10.21832/9781847691941

Charles, C. (2018). Backtalk: Visual language and the representation of black women. Florida Antlantic University.

China Daily. (2017). Mandarin is now rapidly becoming a global http://www.chinadaily.com.cn/opinion/201710/13/content_33190150.htm

Creswell, J. W. (2014). Research design: qualitative, quantitative, and mixed methods approaches (Fourth). SAGE Publications Ltd.

Cystal, D. (2003). English as a global language. In The Palgrave Handbook of Economics and Language (2nd Ed.). Cambridge University Press. https://doi.org/10.1007/978-1-137-32505-1

Dahl, G. R. (2007). Advertising for dummies (2nd Editio). Wiley Publishing, Inc.

Dearden, J. (2014). English as a medium of instruction-a growing global phenomenon. British Council.

Devereux, G. (1966). The exploitation of ambiguity in Pindaros O. 3.27. Rheinisches Museum Für Philologie, 4, 289-298.

Dewi, R. K. (2021). Video viral pelajar "Enggak bisa Bahasa Inggris”, ini kisahnya hingga dapat beasiswa. https://www.kompas.com/tren/read/2021/01/23/10300 0465/video-viral-pelajar-enggak-bisa-bahasa-inggrisini-kisahnya-hingga-dapat?page $=$ all

Dubard, C. A., \& Gizlice, Z. (2008). Language spoken and differences in health status, access to care, and receipt of preventive services among US Hispanics. American Journal of Public Health, 98(11), 20212028. https://doi.org/10.2105/AJPH.2007.119008

Dwita, D., \& Wijayani, I. (2018). Gender equality in media television (semiotics analysis of fair and lovely advertisement issue of marriage or master degree). Komuniti: Jurnal Komunikasi Dan Teknologi Informasi, 10(1), 44-53.

Feramayasari, K., \& Wiedarti, P. (2020). A critical discourse analysis on Shopee 12.12 Birthday Sale advertisement. JELTL: Journal of English Language Teaching and Linguistics. 5(1), 121-130.

Florina, I. D. (2014). Representasi represi orde baru terhadap buruh (studi saluran komunikasi modern Christian Metz dalam film Marsinah) (Cry Justice). Journal of Rural and Development, 5(2), 181-192.

Formentelli, M. (2017). Taking stance in English as a lingua franca: Managing interpersonal relations in academic lectures (Vol. 2). Cambridge Scholars Publishing.

Gall, M. D., Gall, J. P., \& Borg, W. R. (2003). Educational research: an introduction (Seventh). Pearson Education, Inc. https://doi.org/10.4324/9781003008064-1

Graddol, D. (2000). The future of Englishes?: A guide to forecasting the popularity of the English language in the 21st century. The British Council. https://doi.org/10.1017/S0266078400010816

Gramsci, A. (1971). Selections from the prison notebooks (Q. Hoara \& G. N. Smith (eds.)). International Publishers. https://doi.org/10.1080/10286630902971603

Grimaldi, J., Hadeler, D., Richards, S., Berger, R., Zimmerman, J., Bromley, E. W., Dapper, G. S., Toth, M., Santry, C., \& Allen, P. S. (2003). Inside the minds: The art of advertising: CEOs from BBDO, mullin advertising \& more on generating creative campaigns \& building successful brands. In Building (Vol. 2003). Aspatore Books.

Guba, E. G. (1981). Criteria for assessing the trustworthiness of naturalistic inquiries. Educational Communication \& Technology, 29(2), 75-91. https://doi.org/10.1007/BF02766777

Hasan, A. D. (2018). Aesthetic study and symbolic meaning of decoration in traditional wedding. International Conference on Business, Economic, Social Sciences and Humanities (ICOBEST 2018), 225, 332-335. https://doi.org/10.2991/icobest18.2018 .110

Hoffman, B. Y. (2016). Online responses to a multilingual Super Bowl ad: is 'America the Beautiful' by any other language still America, the beautiful? International Journal of Multilingualism, 13(2), 213229. https://doi.org/10.1080/14790718.2015.1094075

Israel, J. I. (1995). The Dutch Republic: Its rise, greatness and fall, 1477-1806: Oxford history of early modern Europe. Oxford University Press.

Jewitt, C., Bezemer, J., \& O’Halloran, K. (2016). Introducing multimodality. Routledge. 
https://doi.org/10.4324/9781315638027

Jones, S. E., \& Yarbrough, A. E. (1985). A naturalistic study of the meanings of touch. Communication Monographs, 52(1), 19-56. https://doi.org/10.1080/03637758509376094

Jonesa, R., Jufrizal, \& Wahyuni, D. (2018). The hegemony of English in Indonesian movies titles 2016. EJournal of English Language \& Literature, 7(4), 396404.

Kachru, B. B. (1986). The power and politics of English. World Englishes, 5(2-3), 121-140. https://doi.org/10.1111/weng.1986.5.issue-2-3

Kachru, B. B. (1988). The sacred cows of English. English Today, 4(4), 3-8. https://doi.org/10.1017/S0266078400000973

Kachru, B. B. (1994). Englishization and contact linguistics. World Englishes, 13(2), 135-154. https://doi.org/10.1111/j.1467-971X.1994.tb00303.x

Kachru, B. B. (1996). World Englishes: Agony and ecstasy. Journal of Aesthetic Education, 30(2), 135155 .

Kachru, B. B. (2001). World Englishes and culture wars. In T. C. Kiong (Ed.), Ariels: Departures and returns: Essays for Edwin Thumboo (pp. 392-414). Oxford University

Press. https://doi.org/10.1002/9780470757598.ch25

Kehoe, M. von L. (2008). The paradox of post-colonial historic preservation: Implications of Dutch heritage preservation in modern Jakarta. E-Polis: Online Student Journal of Urban Studies, 2, 1-20.

Kirkpartrick, A. (2011). English as a medium of instruction in Asian education (from primary to tertiary): Implications for local languages and local scholarship. In L. Wei (Ed.), Applied linguistics: Review 22011 (pp. 99-120). Walter de Gruyter

Landry, R., \& Bourhis, R. Y. (1997). Linguistic landscape and ethnolinguistic vitality: An empirical study. Journal of Language and Social Psychology, 16(1), 23-49. https://doi.org/10.1177/0261927X970161002

Lauder, A. (2008). The status and function of English in Indonesia: A review of key factors. Makara, Sosial Humaniora, 12(1), 9-20. https://doi.org/10.7454/mssh.v12i1.128

Maguth, B. M., Dustman, J., \& Kerr, M. (2013). Reexamining the Statue of Liberty: Different perspectives on history and the promise of America. Social Studies and the Young Learner, 25(4), 9-14. papers3://publication/uuid/4DAF0281-5815-44EE947B-751C35662EF8
Manan, S. A., David, M. K., Dumanig, F. P., \& Channa, L. A. (2017). The glocalization of English in the Pakistan linguistic landscape. World Englishes, 36(4), 645-665. https://doi.org/10.1111/weng.12213

Master, P. (1998). Positive and negative aspects of the dominance of English. TESOL Quarterly, 32(4), 716727. https://doi.org/10.2307/3588002

McKinney, C. (2007). 'If I speak English, does it make me less black anyway?' Race' and English in South African desegregated schools. English Academy Review, 24(2), 6-24. https://doi.org/10.1080/10131750701452253

Mehrabian, A. (1969). Methods \& designs: Some referents and measures of nonverbal behaviour. Behavior Research Method and Instruction, 1(6), 203-207.

Merriam, S. B. (2009). Qualitative research: A guide to design and implementation (2nd Edition). John Wiley \& Sons, Inc. http://dx.doi.org/10.1016/j.encep.2012.03.001

Metz, C. (1991). Film language: A semiotics of the cinema. The University of Chicago Press.

Mianda, G. M. (2014). Reading Awa Thiam's La parole aux Négresses through the lens of feminisms and hegemony of English language. Atlantis: Critical Studies in Gender, Culture \& Social Justice, 36(2), 819.

Mizuta, A. (2009). The unchanged images of English in changing Japan: From modernization to globalization. Intercultural Communication Studies, 18(2), 38-53.

Modiano, M. (2001). Linguistic imperialism, cultural integrity, and EIL. ELT Journal, 55(4), 339-347. https://doi.org/10.1093/elt/55.4.339

Morton, J. L. (2021a). The meaning of blue: Color matters. https://www.colormatters.com/the-meanings-ofcolors/blue

Morton, J. L. (2021b). The meaning of orange: Color matters. https://www.colormatters.com/the-meaningsof-colors/orange

Morton, J. L. (2021c). The meanings of colors: Color matters. https://www.colormatters.com/colorsymbolism/the-meanings-of-colors

OECD. (2016). Education at a glance: OECD indicators 1997. OECD Publishing. http://www.oecd.org/dataoecd/41/25/43636332.pdf

Pahamy. (2021). "Gak Bisa Bahasa Inggris!” https://www.youtube.com/watch?v=nLRD91PpiJk

Pennycook, A. (2017). The cultural politics of English as an international language. Routledge. 
Prasad, B. B. N. (2017). Stylistic and linguistic features of English in advertisements. National Conference on Marketing and Sustainable Development, 586-592.

Riani, R. R., Hidayat, D. N., \& Alek, A. (2021). Diction associative meaning: The case of men and women face wash products in Indonesia. Elsya: Journal of English Language Studies, 3(2), 86-93. https://doi.org/10.31849/elsya.v3i2.6185

Saputra, E., \& Saputra, A. (2020). A new language policy. Linguists (Journal of Linguistics and Language Teaching), 6(1), 18-35. https://doi.org/http://dx.doi.org/10.29300/ling.v6i1.29 69

Saputri, N. I., Hidayat, D. N., Alek, \& Eviyuliwati, I. (2021). An analysis of speech act in beauty product advertisements in television broadcast. JELTL (Journal of English Language Teaching and Linguistics), 6(1), 75-84. http://jeltl.org/index.php/jeltl/article/view/483/pdf

Schreier, M. (2012). Qualitative content analysis in practice. SAGE Publications Ltd.

Schunk, D. H., \& Mullen, C. A. (2012). Self efficacy as an engaged learner. In S. L. Christenson, C. Wylie, \& A. L. Reschly (Eds.), Handbook of research on student engagement (pp. 219-235). Springer. https://doi.org/10.1007/978-1-4614-2018-7

Seidlhofer, B. (2005). English as a lingua franca. ELT Journal, 59(4), https://doi.org/10.1093/elt/cci064

Shank, G., Brown, L., \& Pringle, J. (2014). Understanding education research: A guide to critical reading. Paradigm Publishers.

Sherzer, J. (1991). The Brazilian thumbs-up gesture. Journal of Linguistic Anthropology, 1(2), 189-197. https://doi.org/10.1525/jlin.1991.1.2.189

Stam, R., Burgoyne, R., \& Flitterman-lewis, S. (2005). New vocabularies in film semiotics: Structuralism poststructuralism and beyond. Routledge.

Sugianto, A., Denarti, R., \& Agung, I. (2021). Uncovering the anti-Islamic sentiment in The New Yorker cover issued on July 21 , 2008: A semiotic analysis. International Journal of English Linguistics, Literature, and Education (IJELLE), 3(1), 44-54. https://doi.org/doi :10.32585/ijelle.v3i1.1450

Sugianto, A., \& Wirza, Y. (2021). Cultural contents of an EFL textbook: How is the potential for students , intercultural communicative competence development during the COVID-19 outbreak? Proceedings of the Thirteenth Conference on Applied Linguistics (CONAPLIN 2020), 546, 1-6.
Syakur, A. A., Rusdiawan, \& Sukri, M. (2018). Text of cigarette advertisement: A semiology study of Roland Barthes. International Journal of Linguistics, Literature, and Culture, 4(3), 72-79. https://doi.org/10.21744/ijllc.v4n3.182

Tenia, N., \& Saripudin, R. (2019). Analysis diction and anaphora language style in Unilever Indonesia products advertisement on television. PROJECT (Professional Journal of English Education), 2(1), 58-64. https://doi.org/10.22460/project.v2i1.p58-64

Tom-Lawyer, O., \& Thomas, M. (2019). Re-evaluating the hegemony of the English language in Western Africa: A critical review of the research (2003 to 2018). International Journal of Applied Linguistics and English Literature (IJALEL), 8(5), 83-95. https://doi.org/10.7575/aiac.ijalel.v.8n.5p.83

Tsotra, D., Janson, M., \& Cecez-Kecmanovic, D. (2004). Marketing on the internet: A semiotic analysis. Proceedings of the Tenth Americas Conference on Information Systems, 4210-4220.

Tussa'diah, H., Anggaini, E., \& Hasibuan, S. H. (2021). Code switching utterances of public figures' vlog in Youtube channel. PROJECT (Professional Journal of English Education), 4(3), 513-520. https://doi.org/10.22460/project.v4i3.p513-520

Wahjuwibowo, I. S. (2018). Semiotika komunikasi-Aplikasi praktis bagi penelitian dan skripsi komunikasi. Mitra Wacana Media.

Wittkower, R. (1939). Eagle and serpent: A study in the migration of symbols. Journal of the Warburg Institute, 2(4), 293-325.

Yano, Y. (2009). The future of English: Beyond the Kachruvian three circle model? In K. Murata \& J. Jenkins (Eds.), Global Englishes in Asian Contexts (pp. 208-225). Palgrave Macmillan. https://doi.org/10.1057/9780230239531

Yuen, K. M. (2011). The representation of foreign cultures in English textbooks. ELT Journal, 65(4), 458-466. https://doi.org/10.1093/elt/ccq089

Zakia, R. D., \& Nadin, M. (1987). Semiotics, advertising and marketing. Journal of Consumer Marketing, 4(2), $5-12$. 